Annals of Warsaw University of Life Sciences - SGGW

Land Reclamation No 42 (1), 2010: 5-16

(Ann. Warsaw Univ. of Life Sci. - SGGW, Land Reclam. 42 (1), 2010)

\title{
Spatial analysis of vegetal cover and sediment yield in Tapacurá river catchment based on remote sensing and GIS
}

\author{
RICHARDE MARQUES DA SILVA ${ }^{1}$, CELSO A.G. SANTOS ${ }^{2}$, \\ SUZANA M. GICO LIMA MONTENEGRO ${ }^{1}$, LEONARDO PEREIRA E SILVA ${ }^{3}$ \\ ${ }^{1}$ Civil Engineering Department, Federal University of Pernambuco, Brazil \\ ${ }^{2}$ Civil and Environmental Engineering Department, Federal University of Paraíba, Brazil \\ ${ }^{3}$ DTI Scholar/CNPq, Federal University of Pernambuco, Brazil
}

\begin{abstract}
Spatial analysis of vegetal cover and sediment yield in Tapacurá river catchment based on remote sensing and GIS. Mapping and assessment of erosion risk is an important tool for planning of natural resources management, allowing researchers to propose modification in land-use properly and implement more sustainable management strategies in the long-term. The Tapacurá river catchment, located in Pernambuco State, Northeastern Brazil, is one of the planning units for management of water resources of Recife Metropilitan Region (RMR), and it is divided into 12 sub-basins. The objective of this study is to evaluate the spatial variability of vegetal cover and sediment yield in this basin through remote sensing and GIS techniques. Maps of the erosivity $(R)$, erodibility $(K)$, topographic $(L S)$, cover-management $(C)$ and support practice $(P)$ factors were derived from the digital elevation model (DEM), climate database, and soil and NDVI maps, taking into account information available in the literature. In order to validate the simulation process, Sediment Delivery Ratio ( $S D R$ ) was estimated. The obtained NDVI map showed vegetation loss during the analyzed period, indicating a distinct contrast between loss and gains of vegetation index. The vegetation and sediment yield mapping showed to be a useful tool for environmental monitoring and management, which can provide satisfactory results when jointly used. The results suggest a mean $S D R$ around 0.9 and estimate the sediment yield as $23.98 \mathrm{ton} / \mathrm{ha} / \mathrm{month}$.
\end{abstract}

Key words: satellite images, sediment yield, Tapacurá river catchment.

\section{INTRODUCTION}

Water erosion is one of the most significant environmental degradation processes, and is produced of rill and interrill erosion. Interrill erosion occurs when soil particles are detached by raindrops and transported by shallow overland flow, whereas, rill erosion is the detachment and transport of soil particles by concentrated flow (Beskow et al. 2009). This detached soil is then transported and delivered as sediment downstream. In areas where the erosion process is advanced, a reduction of soil productivity can occur and the transported sediments, nutrients and agrochemicals contaminate and fill up the water bodies. Soil erosion, which directly impacts on the development of human society, is the one of important problems faced by human being, and thus many nations pay attention to the soil and water conservation (Bingfang et al. 2004).

Several physically-based models have been developed in order to quantify erosion in basins, such as KINEROS2 (Woolhiser et al. 1990; Smith et al. 1995), WEPP (Flanagan and Nearing 1995; 
Flanagan et al. 2007), LISEM (De Roo et al. 1996; De Roo and Jetten 1999), and SWAT (Arnold et al. 1998; Gassman et al. 2007).

The aforementioned have the following disadvantages: (a) need extensive data sets as input and many calibration parameters; (b) require either complex laboratory analyses or hard and expensive field data collection, which may be unfeasible to use in many developing countries; and (c) in spite of having some calibration parameters, the models, except SWAT, do not have an optimization method embedded in the software (Beskow et al. 2009). However, some strength points of these models can be emphasized: (a) they are physically based models, basic processes are incorporated in them; and (b) they take into account spatial variability of input and output, thus better representing the real world.

Other models are based on the most popular Universal Soil Loss Equation USLE and the RUSLE technology, and are most commonly used for soil erosion prediction from agricultural lands and tested for their use in many agricultural watersheds in the world (e.g., Fistikoglu and Harmancioglu 2002; Erdogan et al. 2007; Pandey et al. 2007; Dabral et al. 2008). The USLE is the most widely used empirical erosion model, and estimates soil erosion from an area simply as the product of empirical coefficients, which must therefore be accurately evaluated.

The development of distributed hydrological models has been greatly improved with the application of GIS - Geographic Information Systems technology. In Brazil, while several studies on runoffand sediment yield simulation have been conducted with the combination of distributed hydrological model and GIS (Silva et al. 2007; Silva and Santos 2007) in recent years, most of these investigations are mainly concentrated on experimental watersheds. Under such a background, this present paper aims to explore the suitability of similar modelling techniques in large river basins, i.e, in the representative basin.

The land surface variables, such as $N D V I$ can be derived directly from satellite observations (Ma et al. 2004). Remote sensing from satellites offers the possibility to derive regional distributions of land surface over heterogeneous areas in river basins. Remote sensing data provided by satellites area as means of obtaining consistent and frequent observations of spectral reflectance and emittance of radiation at elements in a patch landscape and on global scale (Sellers et al. 1990).

Several methods using remote sensing measurements are used to estimate the vegetation variables and sediment yield in river basins. Thus, the final objective of this paper was to evaluate the spatial variability of vegetal cover and sediment yield in the Tapacurá river catchment, located in Pernambuco State, Northeastern Brazil, through remote sensing and GIS techniques.

\section{MATERIAL AND METHODS}

\section{Study area description}

This work was accomplished in Tapacurá river catchment, located in Capibaribe river basin, Pernambuco State, Brazil, between coordinates $230000 \mathrm{mE}, 270000$ $\mathrm{mE}$, and $9090000 \mathrm{mN}, 9120000 \mathrm{mN}$, and it has a drainage area around $480 \mathrm{~km}^{2}$ 

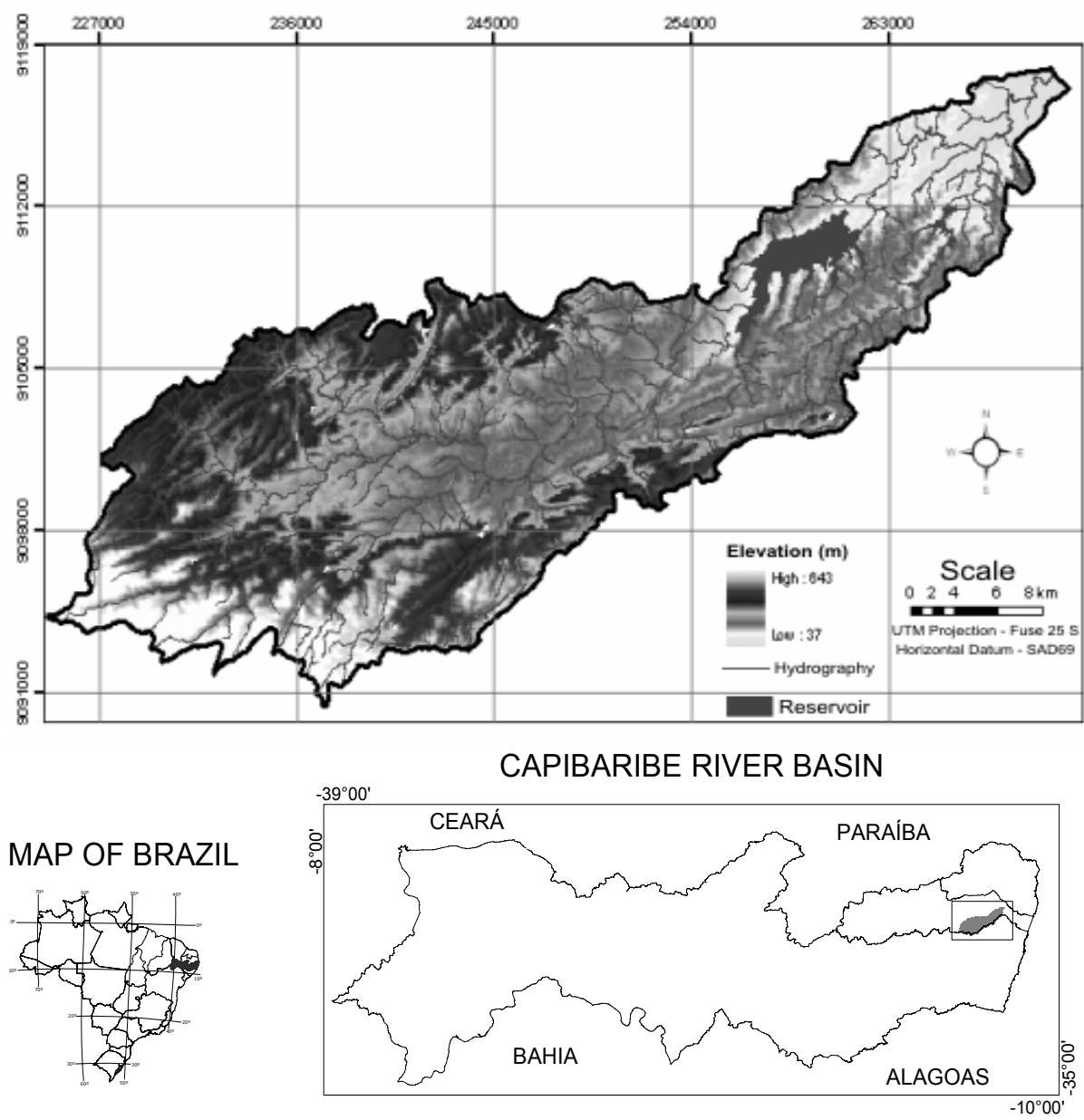

FIGURE 1. Location of Tapacurá river catchment and Capibaripe river basin in Brazil

(Fig. 1). The Tapacurá river catchment is $72.6 \mathrm{~km}$ long, and has a $480 \mathrm{~km}^{2}$ drainage area. It is a tributary of the Capibaribe river basin, which is one of the main rivers in Pernambuco State. The climate is tropical, hot and humid. The annual precipitation of the area is around 1200 $\mathrm{mm} /$ year. The maximum daily rainfall in the area is $175 \mathrm{~mm}$. The annual average temperature is $27^{\circ} \mathrm{C}$, with a daily temperature range of $25-32^{\circ} \mathrm{C}$.

\section{Soil loss and SDR - sediment yield approach}

Sediment yield refers to the amount of sediment measured at a watershed outlet or a point on the waterway. Basically, sediment yield is not equal to the upland erosion (Fistikoglu and Harmancioglu 2002). The ratio of sediment delivered at a given area in the stream system to the gross erosion is the sediment delivery 
ratio for that drainage area. Thus, the annual sediment yield of a watershed is defined as follows:

$$
Y=U S L E \times S D R
$$

where $S D R$ is the sediment delivery ratio, $Y$ is the sediment yield (ton $/ \mathrm{km}^{2}$ ), and USLE is the gross erosion per unit area above a measuring point. The Universal Soil Loss Equation - USLE (Wischmeier and Smith 1978) can be used to estimate soil loss with emphasis on sheet and rill erosion. It does not take sediment deposition into account. The equation can be expressed as follows:

$$
A=R \times K \times L S \times C \times P
$$

where $A$ is the average annual soil loss per unit of area ( $\mathrm{t} / \mathrm{ha} / \mathrm{yr}), R$ is the rainfall-runoff erosivity factor (MJ.mm $\cdot h a \cdot h \cdot y r)$, $K$ is the soil erodibility factor $(\mathrm{t} \cdot \mathrm{h} \cdot \mathrm{MJ} \cdot \mathrm{mm})$, $L S$ is the topographic factor (dimensionless), which includes slope length factor (dimensionless) and slope steepness factor (dimensionless), $C$ is the cover management factor (dimensionless), and $P$ is the support practice factor (dimensionless).

Sediment delivery ratio $(S D R)$ is defined as the fraction of gross erosion that is transported from a given catchment in a given time interval. Williams and Berndt (1977) established a relationship between the delivery ratio and watershed size defined as follows:

$$
S D R=62,7 \times S_{o}^{0.403}
$$

where $S_{o}$ is mean slope of course of main water.

The validation of simulation process was tested on the basis of Sediment Delivery Ratio $(S D R)$ calculated accor- ding to Beskow et al. (2009) and Irvem et al. (2007) as follows:

$$
S D R \%=\frac{T S}{M S L} \times 100
$$

where $T S$ is the transported sediment (ton/ha/yr) to basin outlet and MSL is the mean soil loss in the basin (ton/ha/yr).

\section{Rainfall-runoff erosivity factor $(R)$}

Erosivity is the potential of a rainfall to cause erosion in a given soil with no protection. The $R$ factor takes into account both total precipitation and kinetic energy of raindrops that fall onto the soil, and is affected by rainfall intensity and raindrop size. For estimation of the monthly rainfall-runoff erosivity, the equation developed by Renard and Freimund (1994), which is also known as Fournier Index, was applied. This Index has been used widely in several studies of soil loss and erosivity mapping, e.g., Irvem et al. (2007), and Pandey et al. (2007).

Using daily rainfall data from 12 raingauges during the period of January to December of 2006, the monthly rainfall erosivity of each station was computed for each month of all studied years.

\section{Soil erodibility factor $(K)$}

The determination of the soil erodibility factor was based on the soil textures which exist in Tapacurá river catchment by using the soil map. The soil distribution in the basin and the $K$ factor values are shown in Table 1.

\section{Topographic factor $(L S)$}

The $L S$ factor is used in the USLE to consider the effect of topography on erosion 
TABLE 1 . Soil classification on the Tapacurá river catchment and soil erodibility $(K)$ values

\begin{tabular}{|l|c|c|c|}
\hline Soil types & Area $\left[\mathrm{km}^{2}\right]$ & Area $[\%]$ & $K$ factor $[\mathrm{t} \cdot \mathrm{ha} \cdot \mathrm{h} / \mathrm{ha} \cdot \mathrm{MJ} \cdot \mathrm{mm}]$ \\
\hline Acrisols & 328.4 & 68.4 & 0.00090 \\
\hline Luvisols & 43.5 & 9.1 & 0.00400 \\
\hline Ferralsols & 9.0 & 1.9 & 0.02800 \\
\hline Cromic Luvisols & 6.2 & 1.3 & 0.03200 \\
\hline Fluvisols & 20.2 & 4.2 & 0.06460 \\
\hline Leptosols & 42.5 & 8.9 & 0.00002 \\
\hline Regosols & 5.2 & 1.1 & 0.00060 \\
\hline Planosols & 25.0 & 5.2 & 0.00970 \\
\hline TOTAL & 480.0 & 100.0 & - \\
\hline
\end{tabular}

(Irvem et al. 2007; Erdogan et al. 2007). The topographic factor depends on the slope steepness factor $(S)$ and slope length factor $(L)$ and it is an essential parameter to quantify the erosion generated due to the influence on surface runoff speed. There are different approaches found in the literature for determining the $L$ factor in a grid-based DEM. One of them is based on the upslope contributing area of each cell, which can be computed by the equations described by Desmet and Govers (1996) and Winchell et al. (2008).

In this study, a Digital Elevation Model (DEM) of Tapacurá river catchment was obtained with $90 \mathrm{~m}$ of resolution and was used to generate a slope map, the slope length factor $(L)$ and slope steepness factor $(S)$ for each grid cell on the map. This technique for estimating the $L S$ factor was proposed by Moore and Burch (1986), which was also used by Engel and Mohtar (2007):

$$
L S=\left(\frac{V}{22.13}\right)^{0.4} \cdot\left(\frac{\sin \theta}{0.0896}\right)^{1.3}
$$

where $V$ is runoff depth times the cell size, $\theta$ is the slope angle in degrees.

\section{NDVI-derived cover-management $(C)$ and support practice $(P)$ factors}

The $C$ and $P$ factors are related to the land-use and are reduction factors to soil erosion vulnerability. These factors represent the ratio of soil loss from a given vegetal cover, support practice, type of soil and slope. These are important factors in USLE, since then represent the conditions that can be easily changed to reduce erosion. Therefore, it is very important to have good knowledge concerning land-use in the basin to generate reliable $C$ factor values.

The most common procedure for estimating $C$ factor using the $N D V I$ involves the use of regression equation model derived from the correlation analysis between the $C$ factor values measured in the field and a satellite-derived NDVI (de Jong et al. 1999; de Asis and Omasa 2007). The NDVI expresses the difference between reflectance in the red and near-infrared bands. The Normalized Difference Vegetation Index - NDVI (Rouse 
et al. 1973) expresses the difference between reflectances in the red and near-infrared bands. It is expressed as:

$$
N D V I=\frac{\rho_{\mathrm{IV}}-\rho_{\mathrm{V}}}{\rho_{\mathrm{IV}}+\rho_{\mathrm{V}}}
$$

where $\rho_{\mathrm{IV}}$ is reflectance in the near-infrared band and $\rho_{\mathrm{v}}$, is reflectance in the red band, respectively, bands 4 and 3 of satellite Landsat 5/TM. In this work, six land cover classes from field data were selected: water, urban area, caatinga, sugar-cane, capoeira vegetation, livestock, agriculture, rainforest, reforestation, and poultry farms. The $C$ factor map was developed based on values published in several studies carried out in different areas of Brazil with the same land-use as in this study. The $C$ values for each land use of this basin can be found in Table 2 . The $P$ factor was considered 1.0, due to the lack of information and maps about this factor.

\section{RESULTS AND DISCUSSION}

The $R$ factor represents the erosivity of the climate at a particular location. An average annual value of $R$ was determined from historical weather records and is the average annual sum of the erosivity of individual storms. The result, in the form of an erosivity map and its distribution percentage, is shown in Figure 2a. In this study, an average annual value of $R$ was computed using precipitation data for 12 raingauges stations located around Tapacurá river catchment. The variation of $R$ was represented by an iso-erodent map in $\mathrm{MJ} / \mathrm{ha} \cdot \mathrm{mm} \cdot \mathrm{year}$. The average annual $R$ factor value varies from 2,800 to $5,200 \mathrm{MJ} / \mathrm{ha} \cdot \mathrm{mm} \cdot y e a r$ and the mean value is $4,000 \mathrm{MJ} / \mathrm{ha} \cdot \mathrm{mm} \cdot y e a r$.

Figure $2 \mathrm{~b}$ illustrates the soil types and spatial distribution of the soil erodibility $K$ factor when translated into digital format. The $K$ values in the study area varied from 0.001 to 0.03 and the mean value is $0.02 \mathrm{t} \cdot \mathrm{ha} \cdot \mathrm{h} / \mathrm{MJ} \cdot \mathrm{ha} \cdot \mathrm{mm}$.

The land use classes ( $C$ values) were allocated without considering the seasonal variance (Lee 2004). The NDVI-derived $C$ factor map is shown in Figure 2c. The $C$ factor values varied from 0 to 0.8 and the mean value is 0.4 . Owing to the larger area of agriculture located in the hillside, edge of the valley, higher $C$ factor values occur in that area as well.

Using Eq. (7), $L S$ factor and its distribution percentage were calculated, which

TABLE 2. Portion of each land cover type and $C$ factor for the Tapacurá river catchment

\begin{tabular}{|l|c|c|c|}
\hline Cover-management & Area $\left[\mathrm{km}^{2}\right]$ & Area [\%] & $C$ factor \\
\hline Agriculture & 197 & 41 & 0.54290 \\
\hline Livestock & 148 & 31 & 0.75000 \\
\hline Reforestation & 5 & 1 & 0.00020 \\
\hline Rainforest & 11 & 2 & 0.00010 \\
\hline Capoeira vegetation & 6 & 1 & 0.35000 \\
\hline Caatinga (native vegetation) & 5 & 1 & 0.01780 \\
\hline Sugar-cane & 56 & 12 & 0.00400 \\
\hline Poultry farms & 35 & 7 & 0.81500 \\
\hline Urban area & 9 & 2 & 0.00005 \\
\hline Water & 9 & 2 & 0.00000 \\
\hline
\end{tabular}



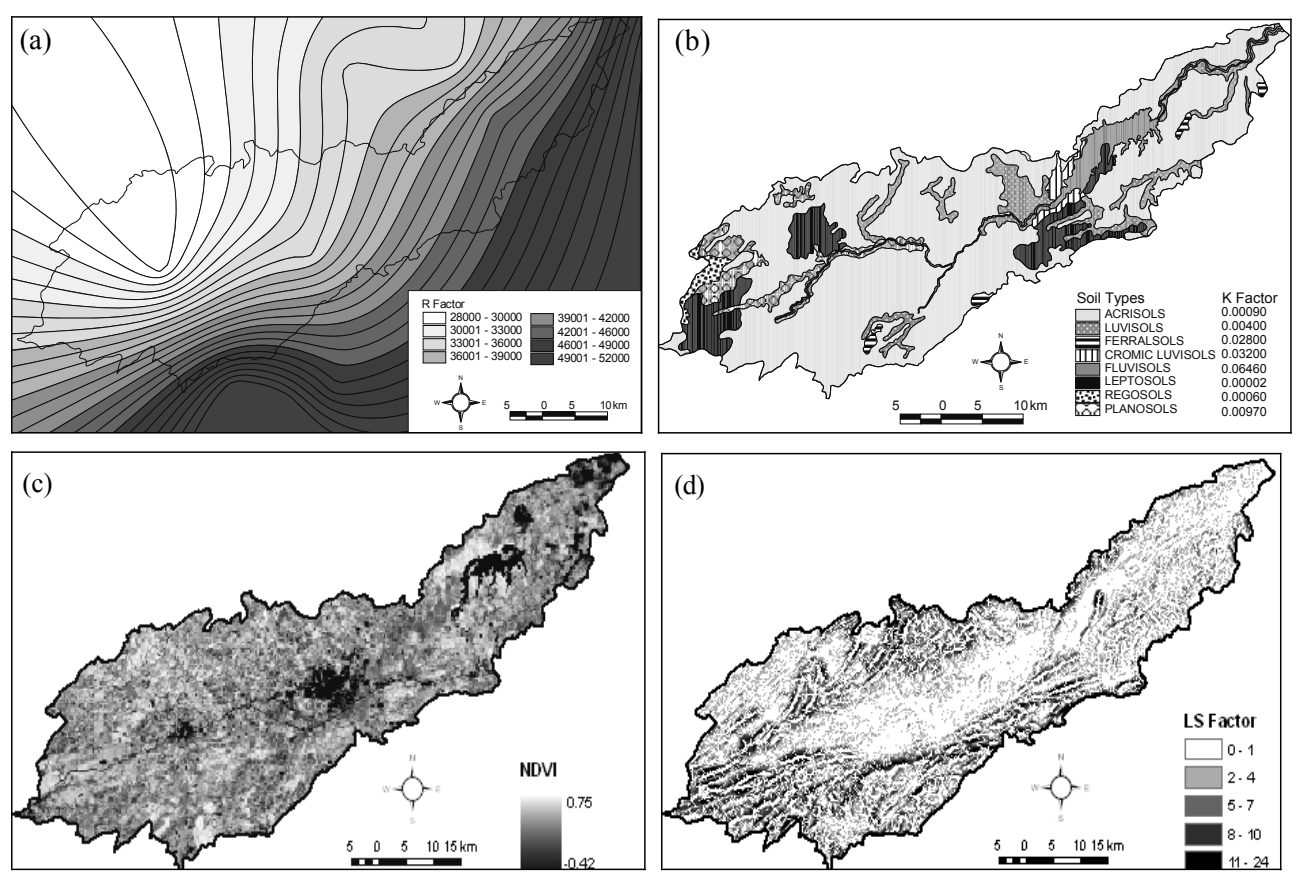

FIGURE 2. (a) Erosivity map, (b) soil map and $K$ Factor, (c) NDVI-C factor map, and (d) map of $L S$ factor of the Tapacurá river catchment

are shown in Figure 2d. The Tapacurá river catchment is characterized by decreasing elevation values from west to east, with a maximum drop of $635 \mathrm{~m}$. The southwest and northwest area of the watershed has the highest variability in elevation, the steepest slopes and, consequently, the highest $L S$ values.

\section{Sediment delivery ratio (SDR) and determination of soil erosion potential}

Determination of sediment delivery ratios, $S D R$, of a specific basin requires sediment data. In the present case, since such data were not available for the selected watershed, the relationship between $S D R$ and watershed area, given in literature by Fistikoglu and Harmancioglu (2002) and
Irvem et al. (2007), is used to roughly estimate the $S D R$ values.

Mean $S D R$ value for the Tapacurá river catchment was 0.9 , which means that $10.0 \%$ of the soil loss generated in the basin was transported to the outlet. For the studied period, average sediment transport was equal to $0.04 \mathrm{t} / \mathrm{ha} / \mathrm{yr}$. Irvem et al. (2007) applied the same procedure for a basin of 21,000 km in Turkey and reported values similar to the ones found in this present work (varying between 0.27 and 1.51 ton/ha/yr). Beskow et al. (2009) applied the same procedure to Grande River Basin, located in Brazil, and they obtained a mean $S D R$ of 0.016 , which means in that case that $1.62 \%$ of the soil loss generated in the basin was transported to the outlet. 
The spatial distributions of the USLE's factors $(R, K, C, P$ and $L S)$ were derived from the rainfall database (erosivity), and maps of soil type, land use (NDVI-derived) and slope, using GIS and remote sensing techniques (Fig. 2). Considering the obtained maps, some important aspects associated with the catchment can be identified. The USLE allows one to quantify soil loss rates (average annual value), in either a lumped or spatially distributed approach.

In this study it should be noted from the soil erodibility map that a considerable area of the basin has a $K$ factor higher than $0.06 \mathrm{t} \cdot \mathrm{ha} \cdot \mathrm{h} / \mathrm{MJ} \cdot \mathrm{ha} \cdot \mathrm{mm}$, which indicates a high susceptibility to water erosion. This natural behavior can be explained because major part of the catchment contains soils of type Acrisols. Analysis of the topographic factor is very important in USLE application, since this parameter characterizes surface runoff speed and, therefore, it is an indicator of soil erosion risk in catchment.
The five parameters layers were all converted into grid diagrams with $90 \mathrm{~m}$ $\times 90 \mathrm{~m}$ cell in a uniform coordinate system. Then the GIS input layers were multiplied, as described by the USLE, to estimate annual soil loss on a pixel-by pixel basis, and the spatial distributions of the soil erosion in the study area was obtained (Fig. 3). As it is seen in this figure, the southwest part of the basin has more erosion productivity than the other parts.

The obtained results showed the susceptible areas to the erosion process within Tapacurá river catchment, and that the mean sediment yield could be in the order of $25.9 \mathrm{t} / \mathrm{ha} / \mathrm{yr}$ (in an area of $4800 \mathrm{ha}$ ). The results also showed that the computed soil losses could be considered as moderate based on the four classes of the basin soil loss as proposed by FAO (1967) in ton/ha/yr: (a) $<10=$ very low, (b) $10-50$ $=$ moderate, (c) $50-200=$ high, and (d) $50-120=$ very high.

The distribution of average annual soil loss for each land use in the Tapacurá

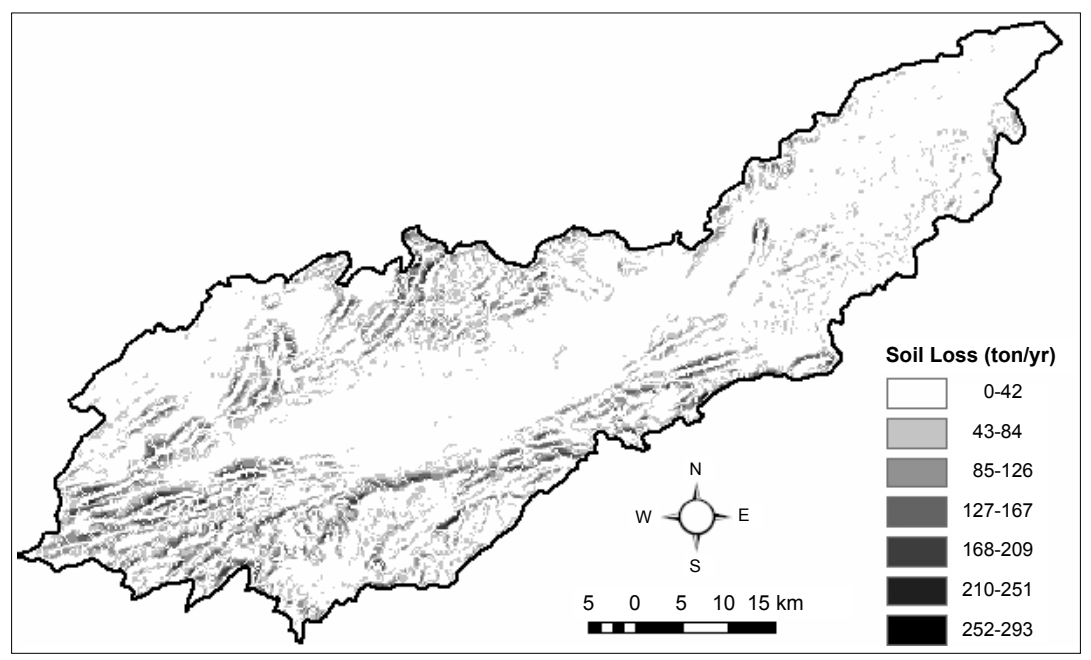

FIGURE 3. Spatial distribution of soil loss in the Tapacurá river catchment 
TABLE 3. Distribution percentage of land use and statistical characteristics of soil loss

\begin{tabular}{|l|r|r|c|c|c|c|r|}
\hline \multirow{2}{*}{\multicolumn{1}{c|}{ Land use }} & \multirow{2}{*}{$\begin{array}{c}\text { Area } \\
{\left[\mathrm{km}^{2}\right]}\end{array}$} & \multirow{2}{*}{$\begin{array}{c}\text { Area } \\
{[\%]}\end{array}$} & \multicolumn{3}{c|}{ Soil loss [ton/yr] } & \multirow{2}{*}{ Std $^{3}$} & \multirow{2}{*}{ Sum } \\
\cline { 5 - 7 } & 197 & 41 & 0.0000 & 275.29 & 30.04 & 38.45 & 655942.06 \\
\hline Agriculture & 148 & 31 & 0.0000 & 292.87 & 28.16 & 40.61 & 482767.75 \\
\hline Livestock & 5 & 1 & 0.0000 & 86.59 & 13.06 & 16.83 & 7953.91 \\
\hline Reforestation & 11 & 2 & 0.0000 & 251.05 & 31.01 & 45.10 & 40381.42 \\
\hline Rainforest & 6 & 1 & 0.0000 & 202.99 & 20.86 & 33.28 & 14267.68 \\
\hline Capoeira vegetation & 5 & 1 & 0.0000 & 239.25 & 62.00 & 62.25 & 39058.27 \\
\hline Caatinga & 56 & 12 & 0.0000 & 209.05 & 15.78 & 23.02 & 108598.84 \\
\hline Sugar-cane & 35 & 7 & 0.0000 & 198.81 & 18.23 & 28.56 & 79298.66 \\
\hline Poutry farms & 9 & 2 & 0.0000 & 109.14 & 8.08 & 12.60 & 8920.30 \\
\hline Urban area & 9 & 2 & 0.0000 & 137.87 & 12.53 & 17.91 & 14612.68 \\
\hline Water & & & & & & \\
\hline
\end{tabular}

${ }^{1}$ Minimum, ${ }^{2}$ Maximum, ${ }^{3}$ Standard deviation.

River catchment is presented in Table 3. It can be observed that the major land use in the basin (Agriculture about 45\%) is predicted to have an average annual soil loss around 30 ton/yr which can be considered high for these areas. This situation is due to the high $C$ factor value (0.55) present in a large part of the area.

Satellite image interpretation could also induce errors due to uncertainties associated with the process of land-use determination. According to Diaz-Ramirez et al. (2008) and Beskow et al. (2009), remote sensing techniques are extremely relevant, but these may result in an important source of error that could affect the land cover mapping and its relationship with hydrology and sediment transport in basins, especially the ones with thousands of $\mathrm{km}^{2}$. Thus, the cover-management ( $C$ factor), applied in the simulation, could be a significant source of error.

In addition, the methodology applied for the estimation of $L S$ factor, it could cause an underprediction of values at some points of the catchment due to longer slope lengths, such as 50,100 or $200 \mathrm{~m}$, which could result in the soil loss underestimate (Desmet and Govers 1996).

\section{CONCLUSIONS}

The present research was conducted in the Tapacurá river catchment, located in northeastern Brazil, in order to assess the applicability of the well-known USLE model, remote sensing and GIS techniques for estimating soil loss.

The results showed a mean $S D R$ in the order of 0.9 and a sediment yield of $23.98 \mathrm{ton} / \mathrm{ha} / \mathrm{month}$, which shows that the soil losses were moderate on approximately half of the area in the Tapacurá river catchment. Thus, it is recommend that the land-use should be changed and that the supporting practices should be implemented in some places within the basin in order to reduce the soil loss rates to a tolerable level, due to the existence of agriculture and livestock land uses over great part of the basin.

The results obtained from the present study demonstrate the importance of land cover for watershed management. The 
greatest part of the soils in the Tapacurá river catchment has mean vulnerability to erosion, high slope steepness and high rainfall-runoff erosivity factor, varying from 2.800 to $5.200 \mathrm{MJ} / \mathrm{ha} \cdot \mathrm{mm} \cdot$ year.

The integration of USLE with remote sensing and GIS techniques to model the potential for soil erosion should to be of great relevance for this type of study. The results showed that the approach of to quickly and simply represent data in order to quantitatively determine soil loss and predict erosion hazard over large area by the USLE in a GIS environment the USLE could be considered useful.

Acknowledgments: The authors wish to thank the Hydraulic Laboratory of the Federal University of Pernambuco, Brazil, for providing the database, digital maps and others resources. The authors are supported by CNPq, FACEPE and MCT/CT-HIDRO/FINEP.

\section{REFERENCES}

ARNOLD J.G., SRINIVASAN R., MUTTIAH R.S., WILLIAMS J.R., 1998: Large area hydrologic modeling and assessment: part I. Model development. J. Am. Water Res. Assoc. 34(1), 73-89.

BESKOW S., MELLO C.R., NORTON L.D., CURI N., VIOLA M. R., AVANZI J.C., 2009: Soil erosion prediction in the Grande River Basin, Brazil using distributed modelling. Catena $79,49-59$.

BINGFANG W., MIAOMIAO L., CHANGZHEN Y., WEIFENG Z., CHANGZHEN Y., 2004: Developing method of vegetation fraction estimation by remote sensing for soil loss equation: a case in the upper basin of Miyun Reservoir. IEEE Transactions 1-4.

DABRAL P.P., BAITHURI N., PANDEY A., 2008: Soil erosion assessment in a hilly catchment of North Eastern India using USLE, GIS and remote sensing. Water Resour. Management 22, 1783-1798.
De ASIS A.M., OMASA K., 2004: Estimation of vegetation parameter for modeling soil erosion using linear Spectral Mixture Analysis of Landsat ETM data. J. Photogramm. Engng and Remore Sens. 62, 309-324.

De JONG S.M., PARACCHINI M.L., BERTOLO F., FOLVING S., MEGIER J., De ROO A.P.J., 1999: Regional assessment of soil erosion using the distributed model SEMMED and remotely sensed data. Catena 37, 291-308.

De ROO A.P.J., JETTEN V.G., 1999: Calibrating and validating the LISEM model for two data sets from the Netherlands and South Africa. Catena 37, 477-493.

De ROO A.P. J., WESSELING C.G., RITSEMA C.J., 1996: LISEM: a single event physically-based hydrologic and soil erosion model for drainage basins: I. Theory, input and output. Hydrol. Processes 10, 1107-1117.

DESMET P.J.J., GOVERS G., 1996: A GIS procedure for automatically calculating the USLE LS factor on topographically complex landscape units. J. Soil and Water Conserv. 51, 427-433.

DIAZ-RAMIREZ J.N., ALARCON V.J., DUAN Z., TAGERT M.L., McANALLY W.H., MARTIN J.L., O'HARA C.G., 2008: Impacts of land use characterization in modeling hydrology and sediments for the Luxapallila Creek Watershed, Alabama and Mississippi. Transactions ASABE 51, 139-151.

ENGEL B., MOHTAR R., 2007: Estimating soil erosion using RUSLE and the ArcView GIS. Web Conference. Available in: http://pasture. ecn.purdue.edu/ abe526/resources 1/workshop. Accessed in: 2009 march 01.

ERDOGAN E.H., ERPUL G., BAYRAMIN I., 2007: Use of USLE/GIS methodology for predicting soil loss in a semiarid agricultural watershed. Environmental Monitoring and Assessment 131, 153-161.

F.A.O. - Food and Agriculture Organization (1967) La erosión del suelo por el água. Algunas medidas para combatirla en las tierras de cultivo. Cuadernos de Fomento Agropecuário da Organización de Las Naciones Unidas 81, 207.

FISTIKOGLU O., HARMANCIOGLU N.B., 2002: Integration of GIS and USLE in assessment of soil erosion. Water Resour. Management 16, 447-467.

FLANAGAN D.C., NEARING M.A., 1995: USDA-Water Erosion Prediction Project 
(WEPP) Hillslope Profile and Watershed Model Documentation. NSERL Report No 10, National Soil Erosion Research Laboratory, USDA-Agricultural Research Service,West Lafayette, Indiana. 298p.

FLANAGAN D.C., GILLEY J.E., FRANTI T.G., 2007: Water Erosion Prediction Project (WEPP): development history, model capabilities, and future enhancements. Transactions ASABE 50, 1603-1612.

GASSMAN P.W., REYES M.R., GREEN C.H., ARNOLD J.G., 2007: The soil and water assessment tool: historical development, applications, and future research directions. Transactions ASABE 50, 1211-1250.

IRVEM A., TOPALOGLU F., UYGUR V., 2007: Estimating spatial distribution of soil loss over Seyhan River Basin in Turkey. J. Hydrol. 336, 30-37.

LEE S., 2004: Soil erosion assessment and its verification using the Universal Soil Loss Equation and Geographic Information System: a case study at Boun, Korea. Environmental Geology 45, 457-465.

MA Y., MA W., LI M., SU Z., MENENTI M., TSUKAMOTO O., ISHIKAWA H., KOIKE T., WEN J., 2004: Determination of regional heat fluxes over heterogeneous land surfaces. IAHS Publ. 289, 206-214.

MOORE I.D., BURCH G., 1986: Physical basis of the length-slope factor in the Universal Soil Loss Equation. Soil Sci. Soc. Am. Journal 50, 1294-1298.

PANDEY A., CHOWDARY V.M., MAL B.C., 2007: Identification of critical erosion prone areas in the small agricultural watershed using USLE, GIS and remote sensing. Water Resources Management 21, 729-746.

RENARD K.G., FREIMUND J.R., 1994: Using monthly precipitation data to estimate the $\mathrm{R}$ factor in the revised USLE. J. Hydrol. 157, 287-306.

ROUSE J.W., HAAS R.H., SCHELL J.A, DEERING D.W., 1973: Monitoring vegetation systems in the great plains with ERTS. Proceedings of III ERTS Symposium, NASA SP-351, NASA, Washington, DC, vol. 1, p. 309-317.

SELLERS P.J., RASOOL S.I., BOLLE H.J., 1990: A review of satellite data algorithms for studies of the land surfaces. Bull. Am. Met. Soc. 71(12), 1429-1447.
SILVA R.M., SANTOS C.A.G., 2007: Evaluation of soil loss in Guaraíra basin by GIS and remote sensing based model. J. Urb. Environ. Engin. 1(2), 44-52, doi: 10.4090/juee.2007. v1n2.044052

SILVA R.M., SANTOS C.A.G., SILVA L.P., SILVA J.F.C.B.C., 2007: Soil loss prediction in Guaraíra river experimental basin based on two erosion simulation models. Ambiente \& Água 2(3), 19-33, doi:10.4136/ambi-agua.30

SMITH R.E., GOODRICH D.C., WOOLHISER D.A., UNKRICH C.L., 1995: KINEROS - a kinematic runoff and erosion model. In: Singh, V. J. (Ed.), Computer models of watershed hydrology. Water Resources Publications, Highlands Ranch, Colorado, 697-732.

WILLIAMS J.R., BERNDT H.D., 1977: Sediment yield prediction based on watershed hydrology. American Society Agric. Eng. 20, 1100-1104.

WINCHELL M.F., JACKSON S.H., WADLEY A.M., SRINIVASAN R., 2008: Extension and validation of a geographic information system-based method for calculating the Revised Universal Soil Loss Equation length-slope factor for erosion risk assessments in large watersheds. J. Soil and Water Conserv. 63, 105-111. WISCHMEIER W.H., SMITH D.D., 1978: Predicting rainfall erosion losses. Admin. U.S. Department of Agriculture. Washington, Agriculture Handbook. Sci. and Educ. 357, 58 p.

WOOLHISER D.A., SMITH R.E., GOODRICH D.C., 1990: Kineros, a kinematic runoff and erosion model: documentation and user manual. U.S. Department of Agriculture, Agricultural Research Service, ARS-77, p. 1-130.

Streszczenie: Analiza przestrzenna ilości sedymentu oraz pokrywy roślinnej $w$ zlewni rzeki Tapacura określona na podstawie zdalnych obserwacji oraz analizy GIS. Artykuł przedstawia sposób wykorzystania zebranych w terenie danych dotyczących pokrywy roślinnej oraz ilości sedymentu określonego za pomocą zdalnych obserwacji oraz analizy GIS w celu monitorowania środowiska i zarządzania zlewniami. W pracy wykorzystano metodę USLE-SDR, a także cyfrowy model terenu. Badania prowadzono w zlewni rzeki Tapacura w północno-wschodniej Brazylii. Wyniki sugerują przyjęcie wartości parametru $\mathrm{SDR}=0,9$, a oszacowana wielkość transportu rumowiska wynosi 23,98 t/ha/miesiąc. 
MS. received April 2010

Authors' addresses:

Richarde Marques Da Silva, Suzana M. Gico Lima Montenegro

Civil Engineering Department

Federal University of Pernambuco

58109-970, Recife-PE

Brazil

e-mail: richarde.silva@ufpe.br

\section{Celso A.G. Santos}

Civil and Environmental Engineering Department Federal University of Paraíba

58051-900, João Pessoa-PB

Brazil

Leonardo Pereira E Silva

DTI Scholar/CNPq

Federal University of Pernambuco

58109-970, Recife-PE

Brazil 